Research Article

Araştırma Makalesi

DOI: $10.24011 /$ barofd.910977
Bartın Orman Fakültesi Dergisi,

23(2): 386-398,

15 August/Ağustos, 2021
Journal of Bartin Faculty of Forestry

p-ISSN :1302-0943

e-ISSN :1308-5875

\title{
Sosyal Medya Verileri Kullanılarak Milli Park Ziyaretlerinin Mekânsal ve Zamansal Değişiminin Modellenmesi: Beydağları Sahil Milli Parkı Örneği
}

\author{
Ahmet USLU ${ }^{1 *}$ \\ ${ }^{1}$ Kütahya Dumlupınar Üniversitesi, Tavşanlı Meslek Yüksekokulu, Mimarlık ve Şehir Planlama Bölümü,43300, \\ KÜTAHYA
}

\section{Öz}

Günümüzde milli parklar, ziyaretçi kullanımının artmasıyla birlikte doğa temelli turizm ve rekreasyon faaliyetleri açısından popüler turizm destinasyonları haline gelmiştir. Doğa temelli turizm araştırmaları ve milli parkların yönetimi için ziyaretçilerin davranışları ve tercihleri hakkında gerçek zamanlı verilere ihtiyaç duyulmaktadır. Ziyaretçi verilerini anketler yoluyla elde etmek çok pahalı ve zaman alıcıdır. Bu bağlamda coğrafi etiketli sosyal medya verileri ziyaretçi verilerini toplamak, korunan alanlardaki ziyaret modellerine ilişkin güçlü içgörüler elde etmek için potansiyel bir veri kaynağı olabilir. Bu çalışmada, Beydağları Sahil Milli Parkı'na gelen ziyaretçilerin zamansal ve mekânsal davranış modellerini analiz etmek amacıyla coğrafi etiketli fotoğrafların kullanım potansiyeli araştırılmıştır. Çalışmanın sonuçları, Flickr verilerinin milli parkların özelliklerini değerlendirmek, zamansal ve mekânsal yönlerini analiz etmek için yararlı bir kaynak oluşturduğunu ve gelecekteki araştırmalar için yeni firsatlar sunduğunu ortaya koymuştur.

Anahtar Kelimeler: Milli parklar, konum tabanlı sosyal ă̆, Flickr, coğrafi etiketli fotoğraflar, ziyaretçi davranışı, zamansal-mekânsal analiz.

\section{Modeling Spatial and Temporal Change of National Park Visits Using Social Media Data: The Case of Beydağları Coastal National Park}

\begin{abstract}
Today, national parks have become popular tourism destinations for nature-based tourism and recreation activities, with the increasing use of visitors. Real-time data on the behavior and preferences of visitors are needed for naturebased tourism research and the management of national parks. Obtaining visitor data through surveys are very expensive and time consuming. In this context, geotagged social media data can be a potential data source for collecting visitor data and gaining strong insights into visitor patterns in protected areas. In this study, the potential for the use of geotagged photographs has been investigated in order to analyze temporal and spatial behavior patterns of visitors to Beydağları Coastal National Park. The results of the study revealed that Flickr data provides a useful resource for evaluating the characteristics of national parks, analyzing their temporal and spatial aspects, and offers new opportunities for future research.
\end{abstract}

Keywords: National parks, location-based social network, Flickr, geotagged photographs, visitor behavior, temporal-spatial analysis. 


\section{Giriş}

Korunan alanlar ve özellikle milli parklar, doğa temelli turizm için önemli bir destinasyon haline gelmiştir (Balmford vd., 2009). Doğal koruma alanları, yaban hayatı izleme, kuş gözlemciliği, doğa yürüyüşleri, kampçılık, yürüyüş, fotoğrafçılık ve piknik yapma gibi pek çok turistik faaliyetler için geniş fırsatlar sağlamaktadır (Balmford vd., 2009). Öte yandan, korunan alanlarda ziyaretçi kullanımının toprak, su, bitki örtüsü ve yaban hayatı gibi doğal kaynakları olumsuz olarak etkileyebilir (Manning 2002). Bu nedenle, park yöneticilerinin, bu alanları uygun şekilde yönetmek ve korumak için ziyaretçilerin özellikleri hakkında tutarlı ve doğru bilgilere sahip olması gerekir (Schägner vd., 2017). Ziyaretçi verileri, karar verme, politika oluşturma ve korunan alan yönetiminin izlenmesi için gereklidir (Manning 2002). Ziyaretçileri karakterize eden veriler, talep eğilimlerinin belirlenmesi, tahminlerin oluşturulması, bir park içindeki altyapı ve hizmetlerin tahsisi, bakım görevlerinin planlanması, personel tahsisi ve kaynakların sağlanması bakımından çok önemlidir (Heikinheimo vd., 2017). Ziyaretçilerin zamansal dağılımına ilişkin bilgiler mevsimselliği, ziyaretçi hareketini ve hatta parkların taşıma kapasitesini ölçmek için sıklıkla kullanılmaktadır (Barros vd., 2019).

Ziyaretçileri izlemenin geleneksel yöntemleri arasında anketler, mülakatlar, GPS cihazları veya sayaçlar bulunmaktadır (Cessford ve Muhar 2003). Ancak, verilerin bu araçlarla toplanması genellikle zahmetli, zaman alıcı ve maliyetlidir (Di Minin vd., 2015). Bu noktada kitle kaynaklı veriler, korunan alanlarda ziyaretçi izleme için verimli ve tamamlayıcı bir yaklaşım olarak giderek daha fazla kullanılmaktadır (Levin vd., 2017). Sosyal medya platformlarında kullanıcı tarafından oluşturulan içerik gibi yeni veri kaynaklarının ortaya çıkışı, milli parklarda turizmi ve rekreasyonu değerlendirmek için yeni seçenekler sunmaktadır (Barros vd., 2019). Özellikle fotoğraf paylaşım hizmetlerinden Flickr, uygulama programlama arayüzü (API) aracılığıyla verilerine kolay ve ücretsiz erişim sağlaması açısından ve fotoğraflar, metinler, ses ve video kaydı gibi zengin içeriğe sahip olması bakımından araştırmacılar ve park planlayıcıları için değerli bir veri kaynağı haline gelmiştir (Barros vd., 2020).

Sosyal medya platformlarından elde edilen verilerin potansiyeli, korunan alanlarda doğa temelli turizmi incelemek için bu veri kaynaklarını kullanmaya yönelik ilginin artmasını sağlamıştır (Shoval ve Ahas, 2016). Araştırmalar, temel olarak Flickr ve Instagram gibi fotoğraf paylaşım platformlarından elde edilen coğrafi etiketli verilere odaklanmıştır. Doğa temelli turizm bağlamında sosyal medya verilerinin zamansal ve mekânsal özellikleri, kültürel ekosistem hizmetlerinin dağılımını araştırmak (Arslan ve Örücü, 2020; Gülçin, 2020), milli parklardaki ziyaret oranlarını modellemek (Sessions vd., 2016), parkların popülaritesini ölçmek (Levin vd., 2017), ziyaretçi akışlarının haritasını çıkarmak (Barros vd., 2019; Barros vd., 2020) ve ziyaretçilerin zamansal ve mekânsal kalıplarını belirlemek (Heikinheimo vd., 2017; Kovacs-Györi vd., 2018; Walden-Schreiner vd; Barros vd., 2019; Ullah vd., 2019) için kullanılmıştır.

Bu çalışmada, milli parklardaki zamansal ve mekânsal ziyaret modellerini belirlemek amacıyla coğrafi etiketli sosyal medya verilerinin kullanım potansiyeli araştırılmıştır. Popüler bir fotoğraf paylaşım sitesi olan Flickr'daki coğrafi etiketli fotoğraflar kullanılarak, Beydağları Sahil Milli Parkı'na gelen ziyaretçilerin zamansal ve mekânsal davranış kalıpları; eğilim grafikleri ve yoğunluk haritaları ile derinlemesine analiz edilmiştir. Çalışma, sosyal medya verileri ile korunan alanlarda ziyaretçilerin mekânsal-zamansal davranış özelliklerinin modellenmesi ve haritalanması üzerine çalışan araştırmacılara ulaşmayı hedeflemekte, korunan alanlarda etkili planlama ve sürdürülebilir alan yönetimi kapsamında referans oluşturabilecek yenilikçi bir yaklaşım sunmaktadır.

\section{Materyal ve Metot}

\section{1. Çalışma Alanı ve Veri Kaynakları}

Antalya'nın Kemer ilçesinde yer alan Beydağları Sahil Milli Parkı, 1972 yılında milli park ilan edilmiştir. Milli park Sarısu Mevkiinden başlayıp Gelidonya burnuna kadar uzanmaktadır (Şekil 1). Milli parkın yüz ölçümü 31.165,88 hektardır. Milli parkın kıyı bölgelerinde kızılçam, yüksek bölgelerinde karaçam ve sedir ormanları bulunmaktadır. Milli park flora yönünden de oldukça zengindir. Yirmi iki tanesi parka özgü olmak üzere toplamda bine yakın bitki türü bulunmaktadır. Milli parkta, yaban keçisi, şah kartal, vaşak ve kurt gibi sayıları her geçen gün azalan önemli hayvan türleri barınmakta ve üremektedirler. Caretta carettaların yumurtalarını bıraktığı Çıralı sahilleri koruma altına alınmıştır. Kültürel miras bakımından da zengin olan milli parkta; Idyros, Olympos ve Phaselis Antik Kentleri, Antik Likya Yolu ve Likya'nın sönmeyen ateşi Yanartaş bulunmaktadır (URL-1). 

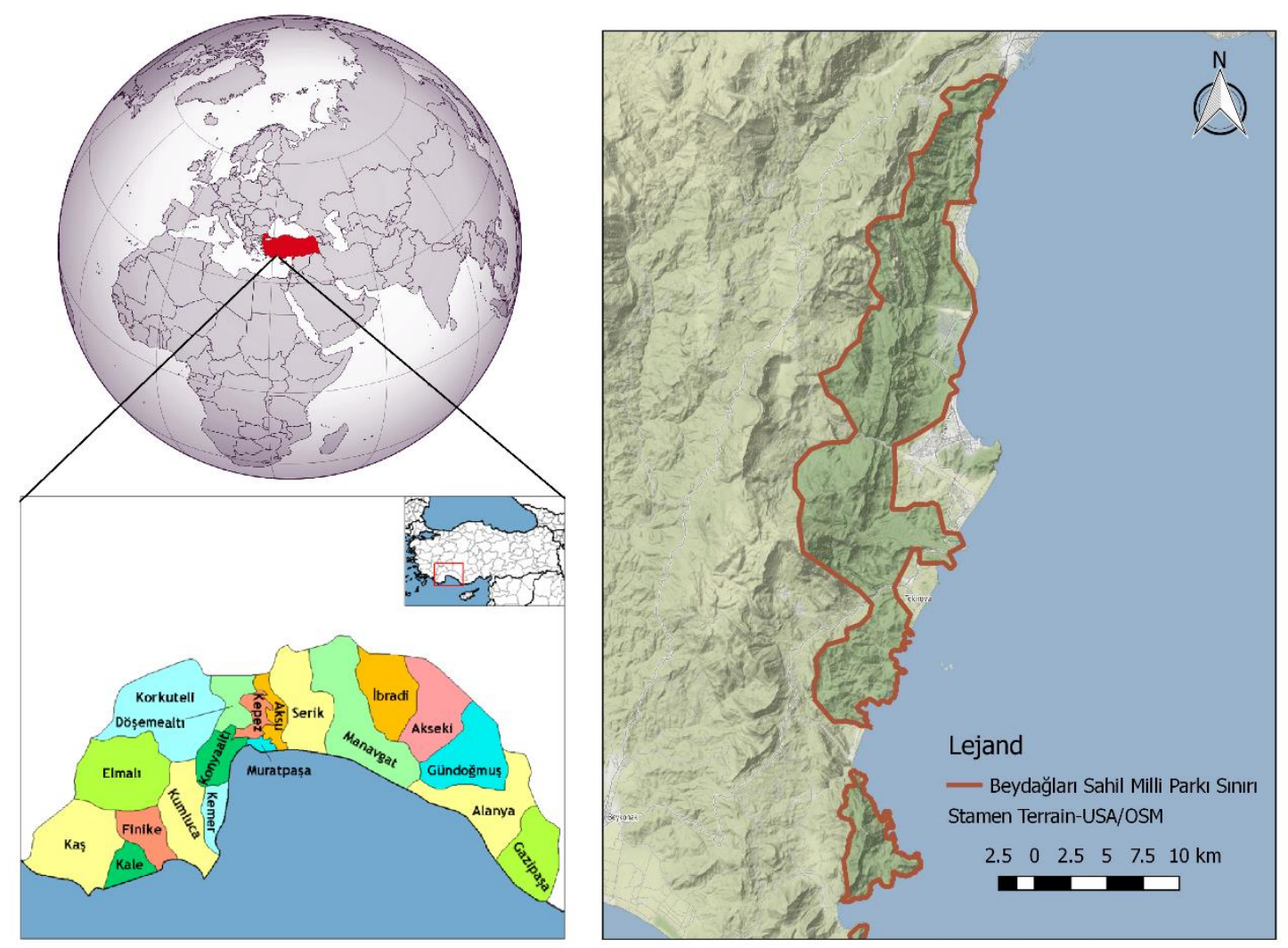

Şekil 1. Çalışma alanının coğrafi konumu.

Çalışmada kullanılan veri seti, popüler bir fotoğraf paylaşım platformu olan Flickr'dan elde edilmiştir. 2004 yılında kurulan Flickr, fotoğrafları ve videoları çevrimiçi paylaşmak için kullanılan bir sosyal ağ sitesidir (URL2). Çalışma alanındaki coğrafi etiketli fotoğraflar, Python (URL-3) komut dosyası kullanılarak Flickr tarafından sağlanan Uygulama Programlama Arayüzü (API) aracılığıyla indirilmiştir. API, ticari kullanım için olmadığı sürece fotoğraflara ücretsiz erişim imkânı sağlamaktadır.

\subsection{Metot}

Çalışmanın yöntemi veri toplama, verilerin analizi ve görselleştirme aşamalarından oluşmaktadır. Şekil 2' de çalışmanın yöntemi için genel bir çerçeve sunulmuştur.

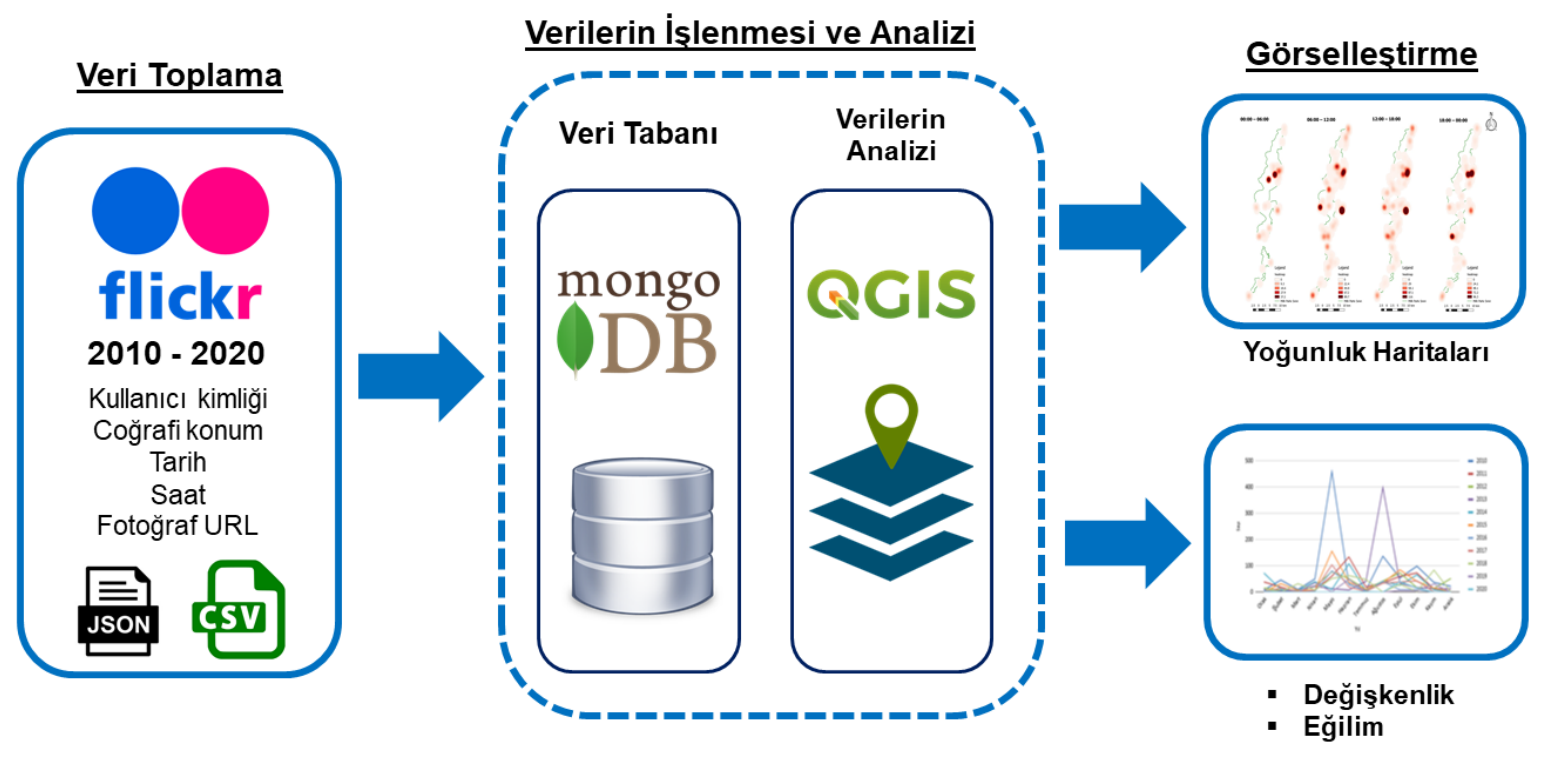

Şekil 2. Çalışmanın yöntemi. 


\subsection{Veri Toplama ve Hazırlama}

Veri toplama aşamasında, coğrafi etiketli fotoğraflara ilişkin meta veri kaydı python tabanlı (URL-3) Flickr (API) (URL-2) kullanılarak JSON (JavaScript Object Notation) formatında bir dosya olarak elde edilmiştir. Meta veri kaydı, kullanıcı kimliği, fotoğraf kimliği, fotoğrafın çekim zamanı, fotoğrafın çekim konumu (enlem ve boylam) ve fotoğraf URL adresi gibi özellikleri içermektedir. Veri seti veritabanında depolama ve ayrıntılı analiz işlemleri için CSV (Virgülle Ayrılmış Değerler) formatında tek bir dosyaya dönüştürülerek, tüm coğrafi etiketli fotoğrafların meta verileri tarihlere göre listelenmiştir. Sonuçlar, bir MongoDB uygulamasındaki ilişkisel bir veritabanında saklanmıştır.

\subsection{Verilerin Analizi ve Görselleştirme}

Bu bölümde, Şekil 2'te gösterildiği gibi Flickr kullanıcılarının dağılımının zamansal ve mekânsal analizi açıklanmıştır. Ziyaretçi davranışındaki değişiklikleri coğrafi etiketli paylaşım sıklıklarına göre keşfetmek için günlük, haftalık, yıllık ve mevsimsel kategorilere ayırarak veri setinin zamansal analizi gerçekleştirilmiştir. Çalışma alanı içindeki ziyaretçi yoğunluğunun mekânsal yapısını analiz etmek için çekirdek yoğunluğu tahminini (KDE) ve QGIS yazılımı kullanılmıştır. KDE, yoğunluğu tahmin etmek için verilerin rastgele örneklemesini kullanan çok değişkenli bir mekânsal analiz tekniğidir (Xie ve Yan, 2008). Konum tabanlı sosyal medya verileri kullanılarak KDE tekniği ile yeşil alanlarda ziyaretçilerin mekânsal kalıpları analiz edilmiştir (Ullah vd., 2019). Son olarak, verilerin mekânsal-zamansal analizleri gerçekleştirilmiş, elde edilen sonuçlar yoğunluk haritaları, tablolar ve grafikler şeklinde görselleştirilmiştir.

\section{Bulgular ve Tartışma}

\subsection{Ziyaretçi ve Mekânsal Dağılımı}

Çalışmada kullanılan veri seti hakkındaki tanımlayıcı bilgiler Tablo 1'de açıklanmıştır.

Tablo 1. Çalışmada kullanılan veri seti.

\begin{tabular}{ll}
\hline Kategori & Açıklama \\
\hline Çalışma Alanı & Beydağları Sahil Milli Parkı \\
Toplam coğrafi etiketli fotoğraf sayısı & 4192 \\
Toplam kullanıcı & 427 \\
Tarih aralığı & 1 Ocak 2010 - 31 Aralık 2020 \\
\hline
\end{tabular}

Coğrafi etiketli veriler QGIS yazılımında zamansal ve mekânsal yoğunluk haritaları şeklinde sunulmak üzere Coğrafi Bilgi Sistemleri (CBS) formatına çevrilmiştir. Şekil 3'te 2010-2020 yılları arasında ziyaretçiler tarafında Beydağları Sahil Milli Parkı sınırları içinde paylaşılan coğrafi etiketli Flickr fotoğraflarının noktasal dağılımı gösterilmiştir. 


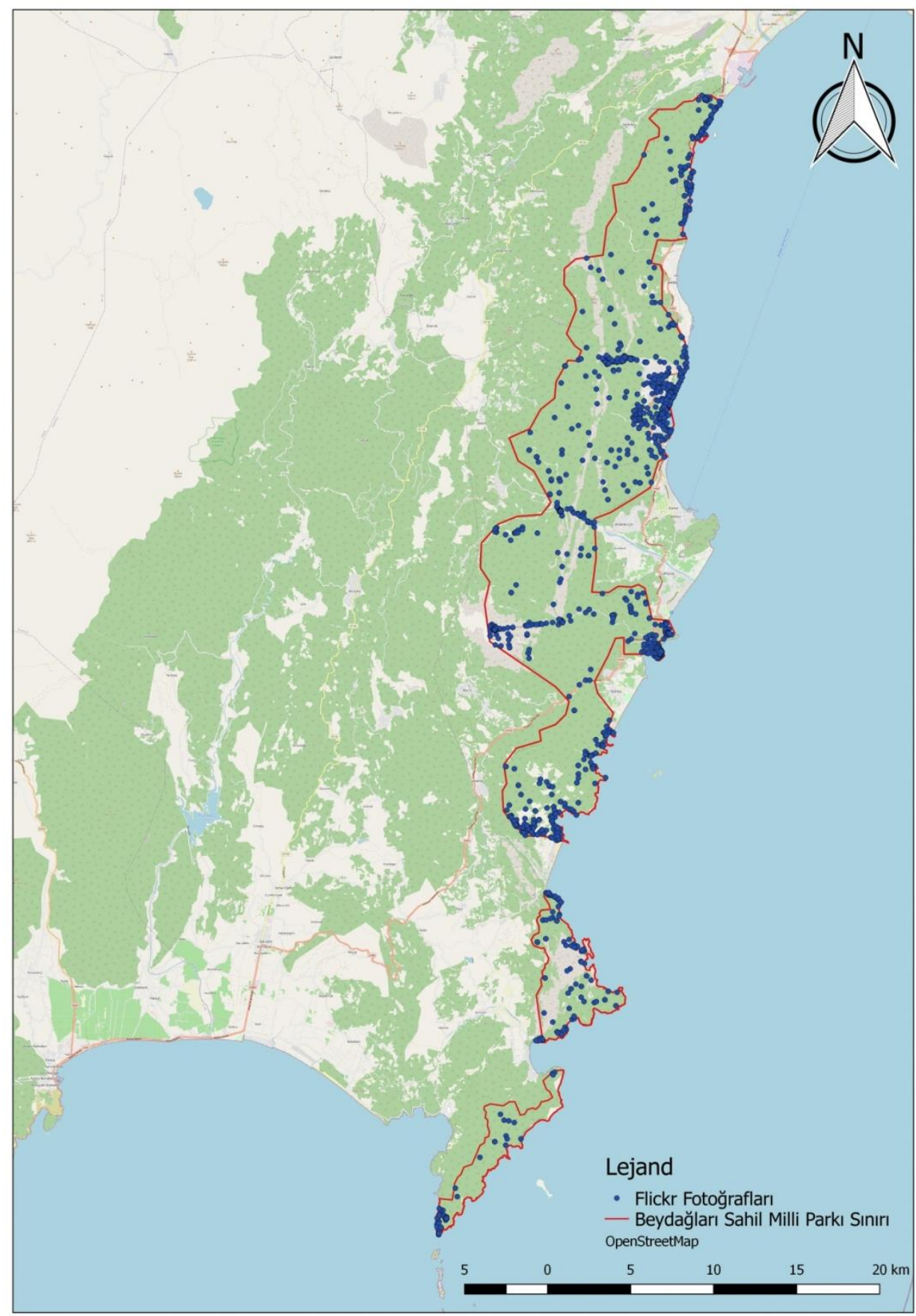

Şekil 3. Coğrafi etiketli fotoğrafların noktasal dağılımı.

\subsection{Zamansal Analiz}

Zamansal analiz için her fotoğrafın çekildiği zaman verisi kullanılmıştır. Beydağları Sahil Milli Parkı sınırları içinde ziyaretçilerin zamansal modelleri hakkında bilgi edinmek için coğrafi etiketli fotoğraf paylaşım sıklıkları zamana göre yıllık, aylık, haftalık, günlük ve mevsimsel dönemlerde aşağıda gösterildiği gibi analiz edilmiştir.

Yıllık modeller, 2010 ve 2020 yılları arasında fotoğraf paylaşımlarının yıllara göre dağılımını göstermektedir (Şekil 4). 


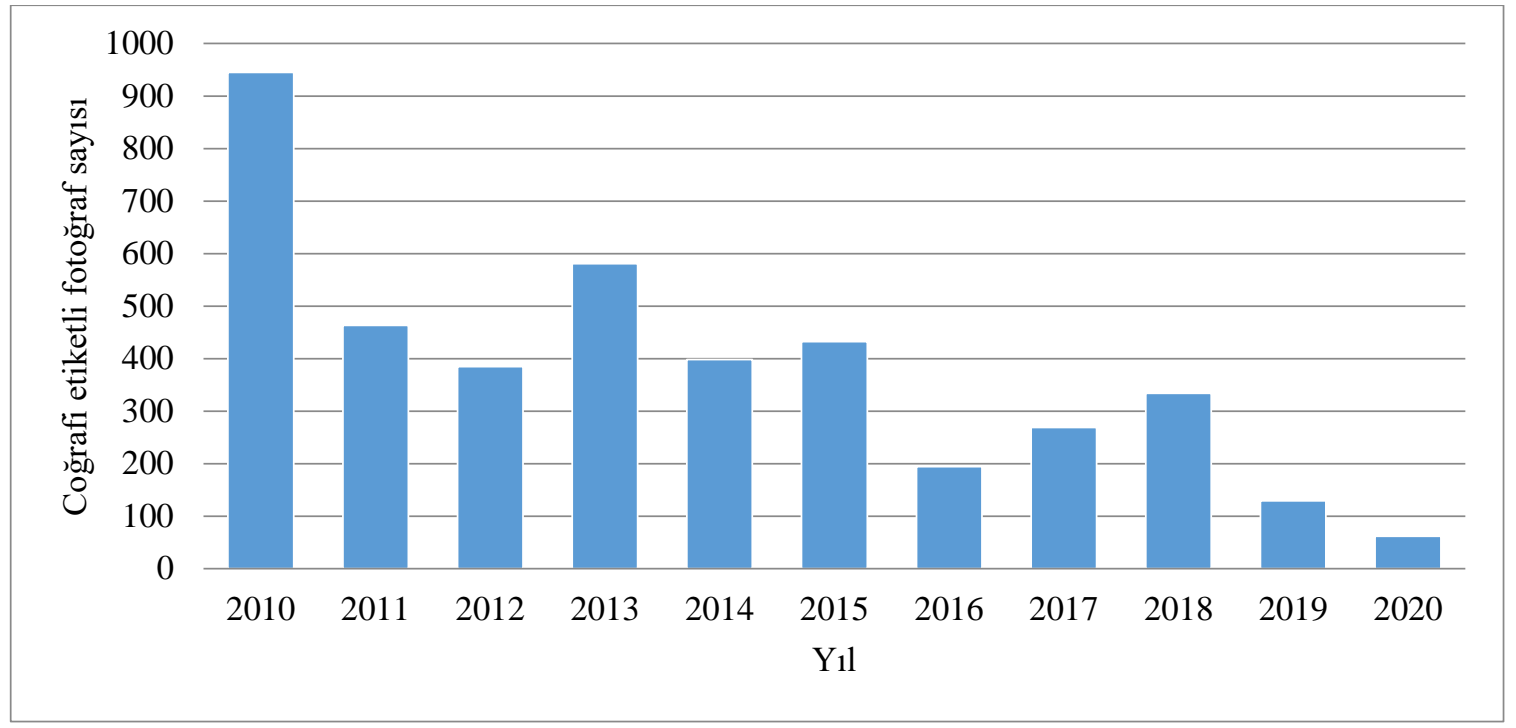

Şekil 4. Coğrafi etiketli fotoğraf sayılarının yıllara göre dağılımı.

Şekil 4 incelendiğinde en fazla paylaşımın 2010 yılında, en az paylaşımın ise 2020 yılında yapıldığı görülmüştür. COVID-19 Pandemisi sürecinde ülkelerin tedbir niteliğinde aldıkları kararlar, seyahat kısıtlamaları, karantinalar, iptal edilen kongre, spor ve sanat etkinlikleri turizm sektörünü doğrudan etkilemiştir. 2020 yıllnda yaşanan düşüş bu durum ile ilişkilendirilebilir.

Aylık modeller, 2010 ve 2020 yılları arasında fotoğraf paylaşım sayılarının aylara göre dağılımını göstermektedir.

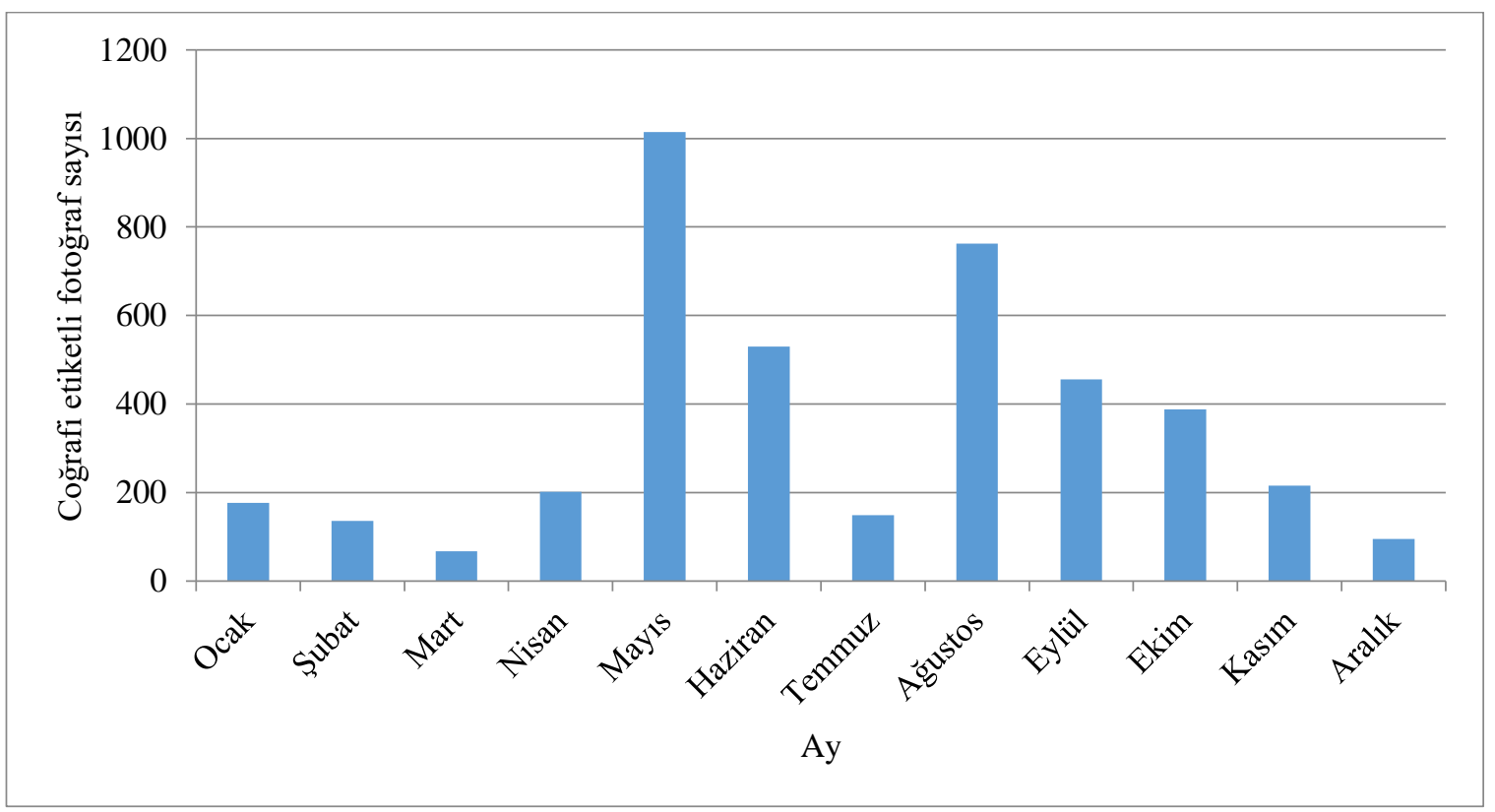

Şekil 5. Coğrafi etiketli fotoğraf sayılarının aylara göre dağılımı.

Şekil 5 incelendiğinde en fazla fotoğraf paylaşımın Mayıs ayında, en az fotoğraf paylaşımın ise Şubat ayında yapıldığı görülmüştür. Beydağları Sahil Milli Parkı'nın 2010-2020 tarihleri arasında genel aylık fotoğraf paylaşım eğilimini gözlemlemek için analiz gerçekleştirilmiştir (Şekil 6). Şekil 6 incelendiğinde 10 yıllık süreçte Mayıs ve Ağustos aylarında yüksek kullanım eğilimi olduğu gözlemlenmiştir. 


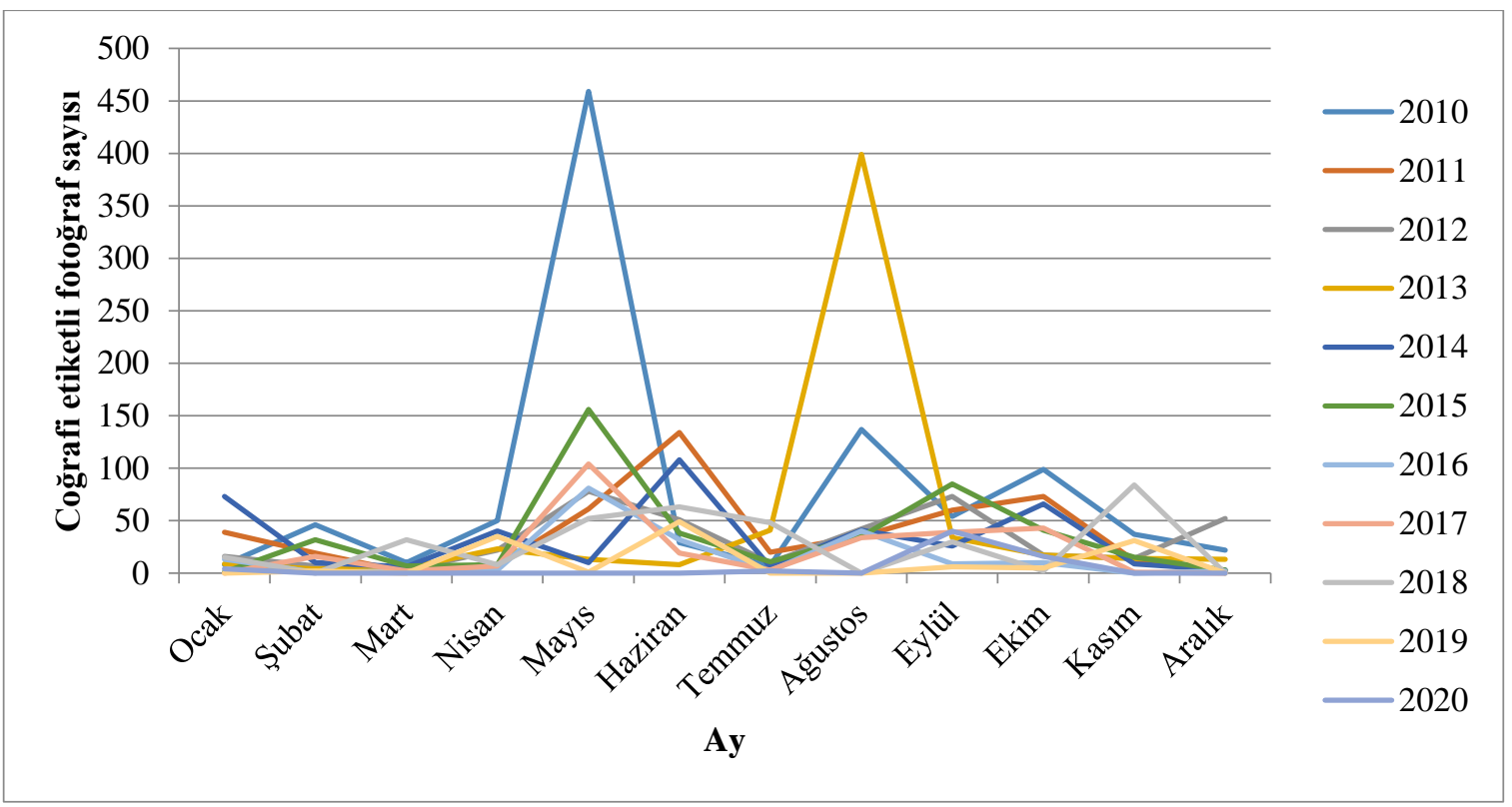

Şekil 6. Beydağları Sahil Milli Parkı'nın yıllara göre aylık fotoğraf paylaşım eğilimi.

Barros vd. (2019), 15 adet milli parka gelen ziyaretçilerin zamansal dağılımını çıkarmak için coğrafi etiketli verilerin kullanımını test etmişlerdir. En yoğun ziyaretlerin Paskalya tatili ve yaz tatiline denk gelen Temmuz ve Ağustos aylarında, en az ziyaretlerin ise Aralık ve Ocak aylarında gerçekleştirildiğini belirlemişlerdir. Ullah vd. (2019), araştırmalarında en yoğun ziyaretlerin Nisan ve Mayıs aylarında, en az yoğun ziyaretlerin ise Ocak ve Şubat aylarında gerçekleştiğini tespit etmişlerdir. Araştırmada sıcaklığın ziyaretçi davranışlarını önemli ölçüde etkileyen faktör olduğu belirtilmiştir. Araşırmanın aylık ziyaret analizi sonuçları bu çalışmanın aylık ziyaret modeli sonuçları ile benzerlik göstermektedir.

Haftalık modeller, haftanın günleri, hafta içi ve hafta sonu yapılan fotoğraf paylaşımlarının dağılımını ve Beydağları Sahil Milli Parkı'nın kullanım durumunu göstermektedir (Şekil 7).

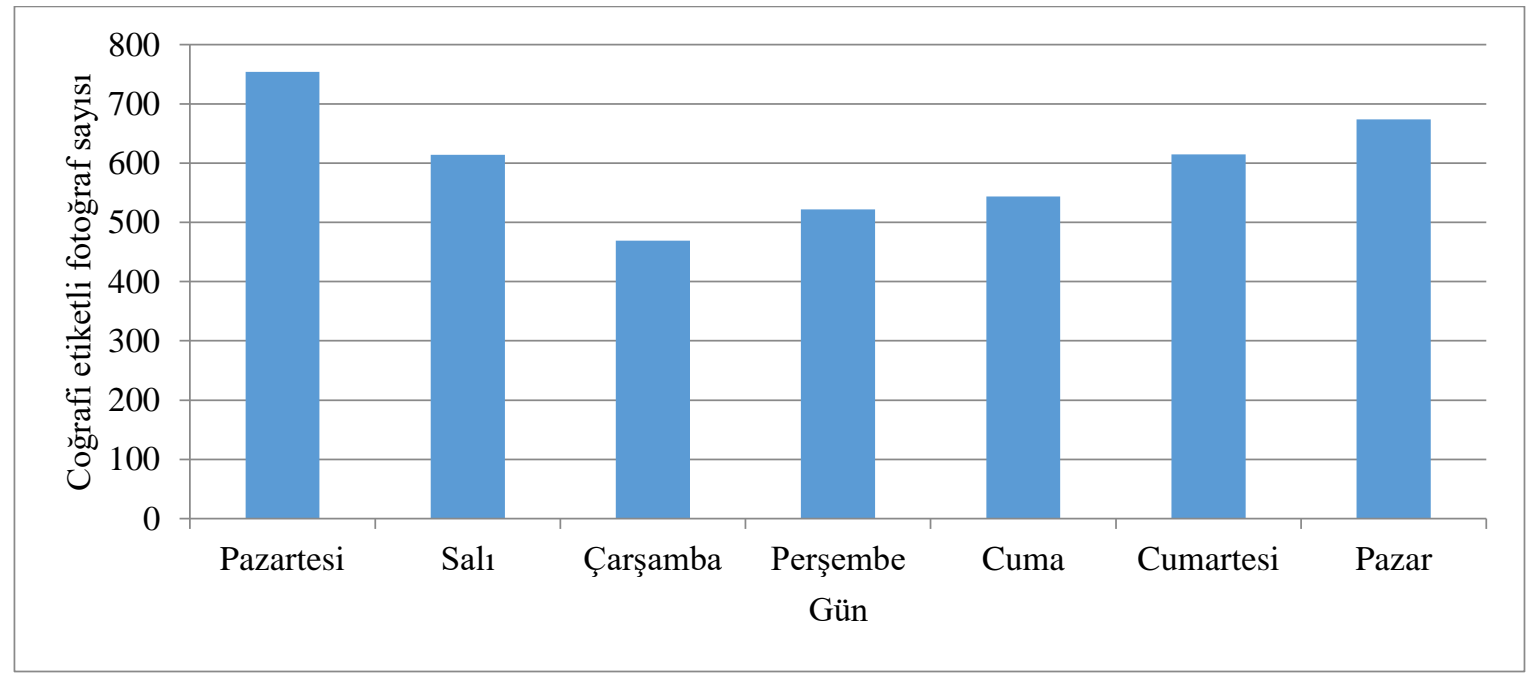

Şekil 7. Coğrafi etiketli fotoğraf sayılarının günlere göre dağılımı.

Şekil 7 incelendiğinde haftalık kalıplar, Cumartesi ve Pazar günlerinin tatil olmasına rağmen, Pazartesi gününde daha fazla paylaşım yapıldığına dair ilginç bir gerçeği ortaya koymaktadır. Bunun yanı sıra, kalan günler normal davranış göstermektedir. Salı, Çarşamba, Perşembe ve Cuma günleri iş günleri olması sebebiyle bu günlerde paylaşım sıklığı nispeten düşük ve neredeyse aynıdır. Barros vd. (2019) araştırmalarında ziyaretlerin hafta sonlarında yoğunlaştığını ortaya koymuşlardır. Araştırmacıların haftanın gününe göre ziyaretçi dağılımı sonuçları bu çalışma ile farklııı göstermektedir. Günlük ziyaretçi analizi, araştırmacıların ziyaretleri hava durumu, kapalı yollar, hafta sonları ve tatiller ile ilişkilendirmesini sağlayabilir. 
Günlük modeller, gün içindeki fotoğraf paylaşımlarının saatlik dağılımını göstermektedir. Gün; 00:00-06:00, 06:00-12:00, 12:00-18:00 ve 18:00-00:00 olmak üzere dört aralığa bölünmüş ve farklı saatlerde ziyaretçilerin fotoğraf paylaşım davranışı gözlemlenmiștir (Şekil 8).

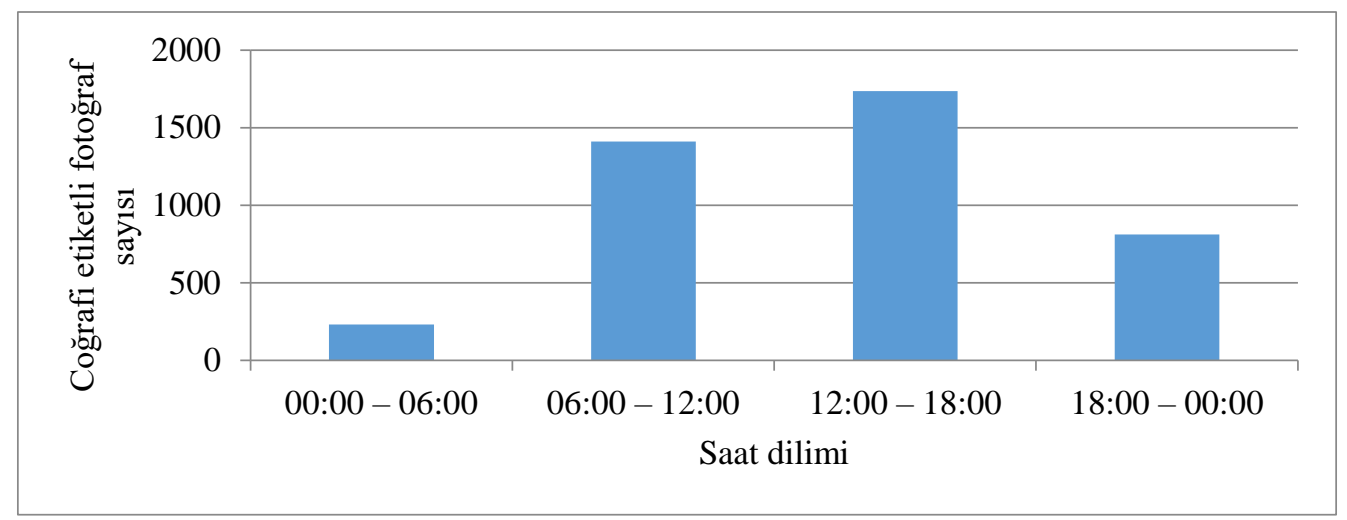

Şekil 8. Coğrafi etiketli fotoğraf sayılarının günlük saat dilimlerine göre dağılımı.

Şekil 8 incelendiğinde ziyaretçi faaliyetlerinin sabah erken saatlerde başladiğı ve gece geç saatlere kadar devam ettiği görülmüştür. En fazla paylaşım 12:00-18:00 saatleri arasında, en az paylaşım ise 00:00-06:00 saatleri arasında yapılmıştır.

Beydağları Sahil Milli Parkı'nın günlük fotoğraf paylaşım eğilimini gözlemlemek için 24 saatlik periyotta analiz gerçekleştirilmiştir (Şekil 9).

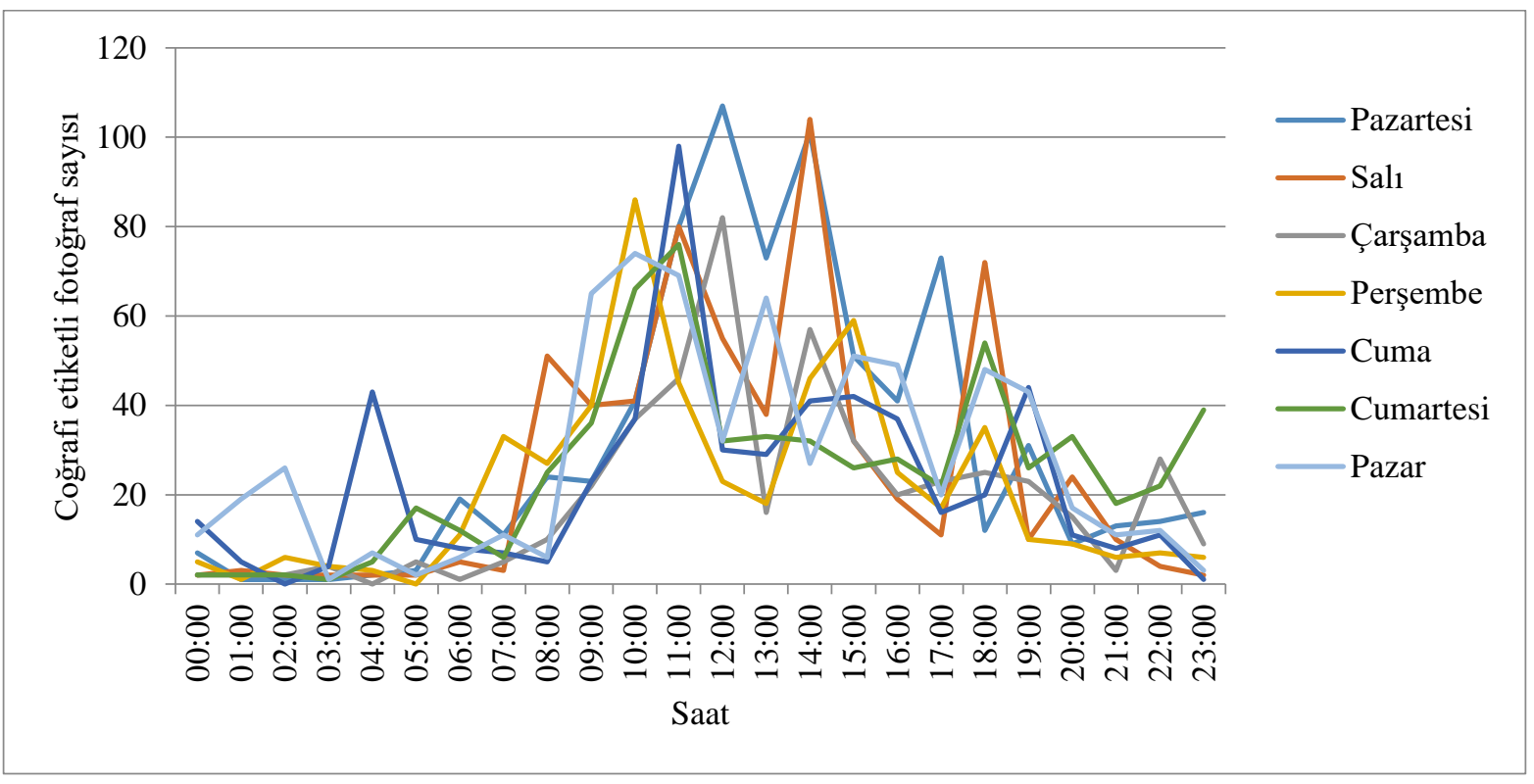

Şekil 9. Beydağları Sahil Milli Parkı’nın günlük saatlere göre fotoğraf paylaşım eğilimi.

Şekil 9 incelendiğinde, sabah saatlerinde (06:00-12:00) ve öğleden sonraki saatlerde (12:00-18:00) yüksek kullanım eğilimi gözlenmektedir. Ancak saat 18: 00'dan itibaren fotoğraf paylaşım eğiliminde bir düşüş olduğu görülmüştür. Barros vd. (2019) çalışmalarında 11:00-15:00 saatleri arasında ziyaretlerin yoğunlaştığını, gece saatlerinde ise yoğunluğun azaldığını tespit etmişlerdir. Araştırmacıların sonuçları bu çalışmanın sonuçları ile benzerlik göstermektedir. Ullah vd. (2019) çalışmalarında en fazla sosyal medya paylaşımının saat 16:00'da gerçekleştirildiğini ve eğilimin gece yarısına kadar sürekli arttığını belirlemişlerdir. Bu bulgu, Şanghay'daki yeşil parkların, Şanghay vatandaşları için hızla önemli eğlence yerleri haline geldiğini göstermektedir.

Mevsimsel modeller ve iklim faktörleri bir parkın işlevselliğini etkileyebilir. İlkbahar, yaz, sonbahar ve kış dönemi için Beydağları Sahil Milli Parkı'na gelen ziyaretçilerdeki mevsimsel değişimler incelenmiştir. 


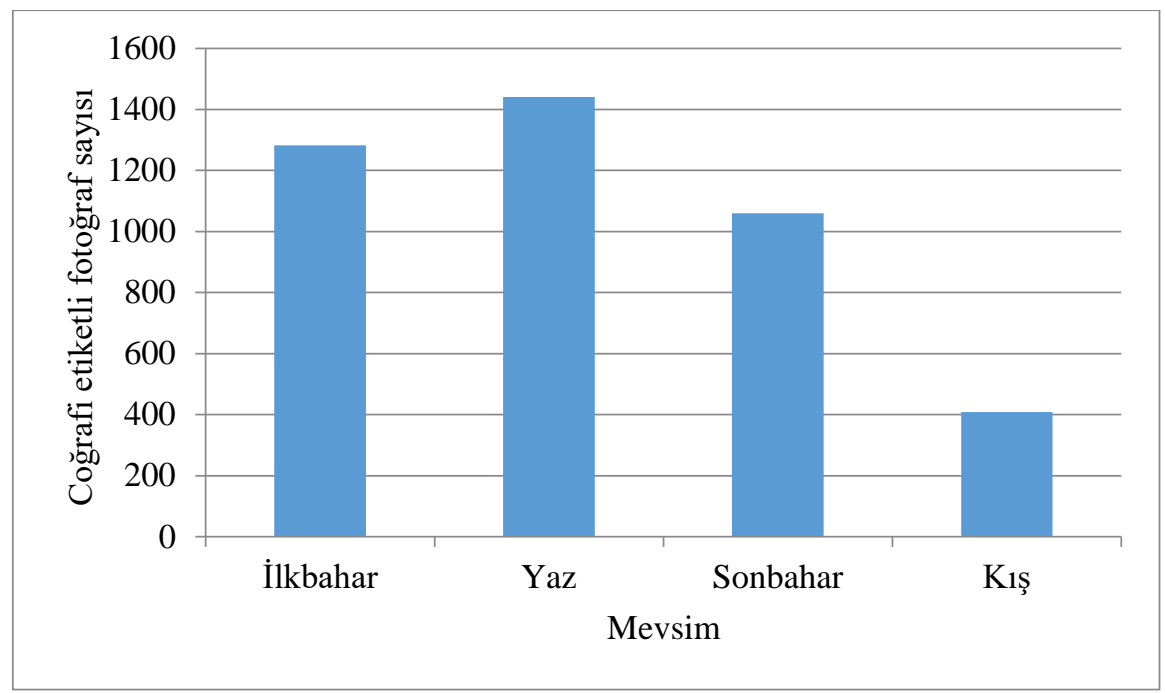

Şekil 10. Coğrafi etiketli fotoğraf sayılarının mevsimlere göre dağılımı.

Şekil 10'daki mevsimsel dağılım grafiği incelendiğinde, yaz ve ilkbahar mevsimlerinde milli parkta daha büyük oranda fotoğraf paylaşımının yapıldığı görülmüştür. Kış mevsiminde yapılan paylaşım sayısı ise oldukça düşüktür. Barros vd. (2019), Ullah vd. (2019) araştırmalarında ziyaretlerin yaz tatiline bağlı olarak yaz mevsiminde yoğunlaştığını, kış mevsimi boyunca sert iklim nedeniyle ziyaretlerin düşük kaldığını bertilmişlerdir. Araştırmacılar park ziyaretlerindeki mevsim değişkenliği açıklamak için sıcaklığı önemli bir faktör olarak tanımlamışlardır. Araştırmaların mevsimsel analize ilişkin sonuçları, bu çalışmanın sonuçları ile benzerlik göstermektedir. Mayıs ve Ağustos aylarında sosyal medya paylaşımlarının çok daha yüksek olması, ilkbahar ve yaz aylarında çok sayıda sosyal medya paylaşımının gerçekleştirildiğini gösteren mevsimsel değişim sonuçlarını desteklemektedir.

\subsection{Mekânsal Analiz}

Bu bölümde, KDE yöntemi kullanılarak Beydağları Sahil Milli Parkı sınırları içinde paylaşılan coğrafi etiketli fotoğrafların mekânsal analizi araştırılmıştır. Flickr'dan alınan coğrafi konum (enlem ve boylam) verileri ile ziyaretçilerin günlük ve mevsimsel periyotlarda faaliyetleri CBS ortamında haritalanmış ve karşılaştırılmıştır. Yoğunluk haritaları QGIS yazılımında KDE fonksiyonunu kullanan Isı Haritası eklentisi özelliği ile üretilmiştir. Haritalar $2000 \mathrm{~m}$ bant genişliğinde Gauss yöntemi ile üretilmiştir.

1 Ocak 2010-31 Aralık 2020 tarihleri arasında paylaşılan toplam coğrafi etiketli fotoğraf yoğunluğu Şekil 11'de gösterilmiştir. Şekil 11 'de, kırmızı renkte gösterilen alanlar daha yüksek insan yoğunluğuna, daha yüksek aktivite sıklığına ve daha yüksek sosyal medya kullanım yoğunluğuna işaret etmektedir. Bir destinasyonun güzelliği görsel estetikten daha fazlasını içerdiğinden, ziyaretçiler muhtemelen doğal özelliklerden etkilenirler. Bireyler kendilerini tamamen kaptırabilecekleri ve tüm duyularını harekete geçirebilecekleri yerleri tercih ederler (Arkema vd., 2021). Arkema vd. (2021), ziyaretin mekânsal dağılımı etkileyen faktörlere ilişkin analizlerinde, mercan resifleri, çamlar ve kumsallar gibi hassas ortamların turist çekme eğiliminde olduğunu, erişim ve konaklama ile ilgili faktörlerin (tüplü dalış merkezlerinin yakınındaki mercanlar ve sık sık feribot ve uçuş yapılan bölgeler gibi) ziyaretçileri cezbettiğini belirtmiştir. 


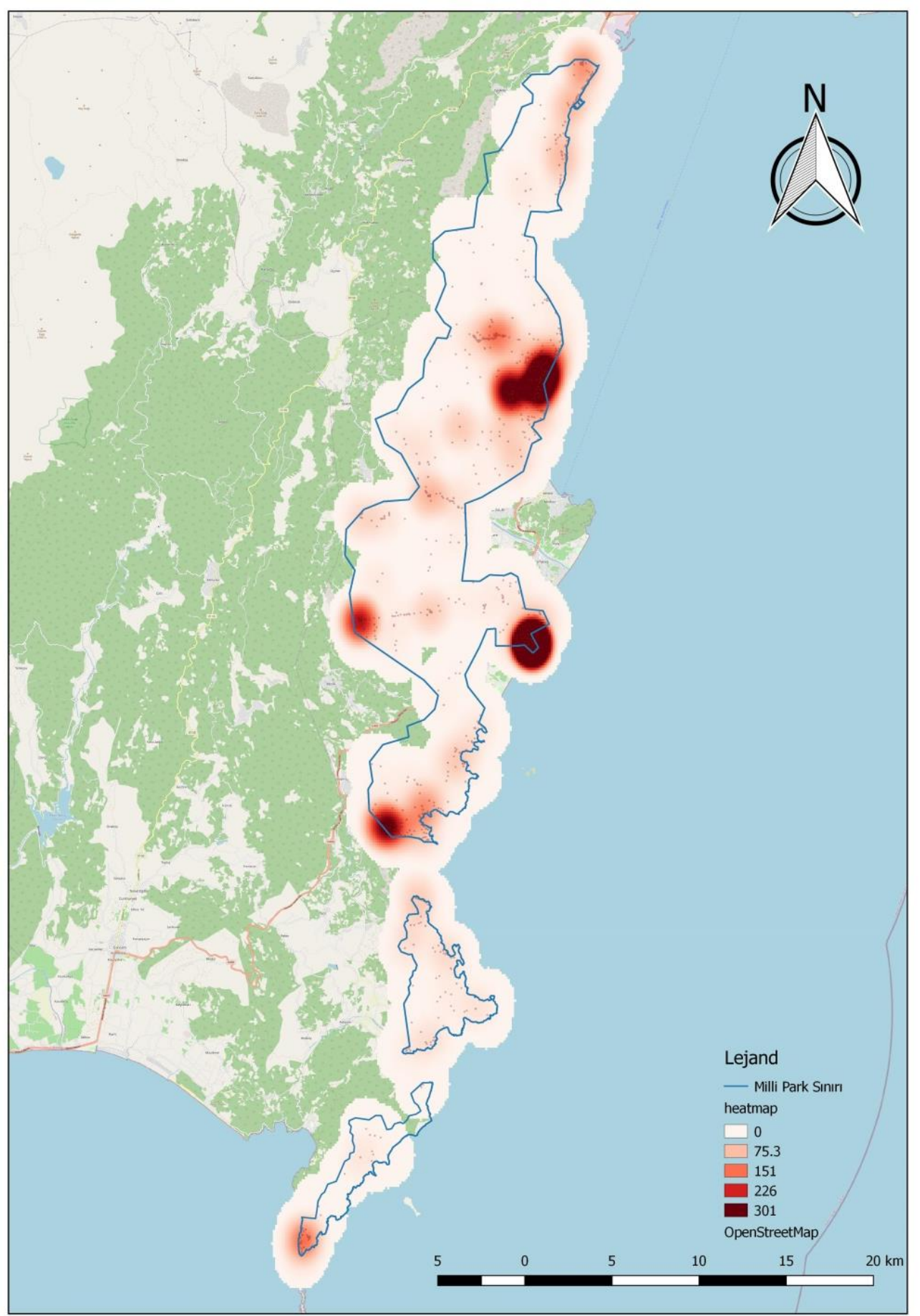

Şekil 11. Beydağları Sahil Milli Parkı'ndaki genel coğrafi etiketli fotoğraf yoğunluğu.

Phaselis Antik Kenti, Likya Yolu, Göynük Kanyonu, Olympos Teleferik hattı ve Yanartaş mekânlarının, ziyaretçi faaliyetlerinin merkezi olduğu görülmüştür. Kernel yoğunluğu haritasında ziyaretçilerin mekânsal tercihlerinin ilgili bölgeler etrafında dağılımını etkileyen çeşitli faktörlerin olduğu tahmin edilmiştir. Phaselis Antik Kenti, Kemer'in 16 km batısında yer alan, MÖ VII. yüzyılda Rodos'lular tarafından kurulmuş Antik Yunan ve Roma şehridir. Phaselis'in coğrafi konumu önemli bir liman kenti olduğunu göstermektedir. Phaselis Antik Kenti'nde tiyatro, üç agora ve hamam kalıntıları bulunmaktadır. Kentin hemen yakınında Phaselis Plajı da yer almaktadır. (URL-1). Phaselis Antik Kenti'nde Kernel yoğunluğunun yüksek potansiyele sahip olmasının sebebi, antik doku ile doğal güzelliklerin birleşiminden meydana gelen kültürel peyzajların estetik açıdan ziyaretçilerin ilgisini yoğun biçimde çekmesi ile ilişkilendirilebilir. Likya Yolu, Fethiye'den başlayarak Antalya'ya kadar uzanan, ülkemizin ilk uzun mesafeli, doğa ve tarihle iç içe muhteşem bir yürüyüş yoludur (URL-1). Tarihi doku ve doğal güzellikleri bir arada bulunduran Likya yolu, manzara deneyimlerine odaklan, dağcılık ve doğa sporları gibi özel 
rekreasyonel faaliyetlerle ilgilenen ziyaretçilerin ilgisini çekmiş olabilir. Göynük Kanyonu, muhteşem doğası, ağaçları, şelaleleri ve havuzları ile doğa sporu tutkunları için eşsiz bir yerdir (URL-1). Göynük Kanyonunun, canyoning, zipline aktiviteleriyle adrenalin dolu bir macera yaşamayı seven ve aynı zamanda bölgenin doğal güzelliklerini keşfetmek isteyen günübirlik ziyaretçiler tarafından tercih ettiği tahmin edilmektedir. Olympos Teleferik hattı Tahtalı Dağı üzerinde konumlanan, 726 metreden 2365 metreye çıkan, 4350 metre uzunluğa sahip Avrupa'nın en uzun teleferik sistemi olarak bilinmektedir (URL-1). Adrenalin seviyesi ve eşsiz manzara seyri yüksek olan yolculuktan sonra gün doğumu, gün batımı ve eşsiz panoramik manzaraları deneyimlemek ve fotoğraflamak isteyen ziyaretçiler tarafından tercih edildiği söylenebilir. Olimpos'un sönmeyen ateşi Yanartaş, Kemer'in Çıralı köyü yakınlarında küçük, tarihi ve turistik önemi olan doğalgaz kaynağıdır (URL-1). Denize yakın manzaralı bir konumda yer alması ve taşlar arasından çıkan alevlerin 2500 senedir yanması itibariyle bu alan ziyaretçilerin ilgi noktası haline gelmiş olabilir.

Günün farklı saatlerinde ziyaretçilerin milli park içindeki davranışlarını gözlemlemek amacıyla, 00:00-06:00, 06:00-12:00, 12:00-18:00 ve 18:00-00:00 zaman dilimlerinde mekânsal analizler gerçekleştirilmiştir. Şekil 12 Beydağları Sahil Milli Parkı'nın mekânsal-zamansal dinamiklerini ortaya koymaktadır.
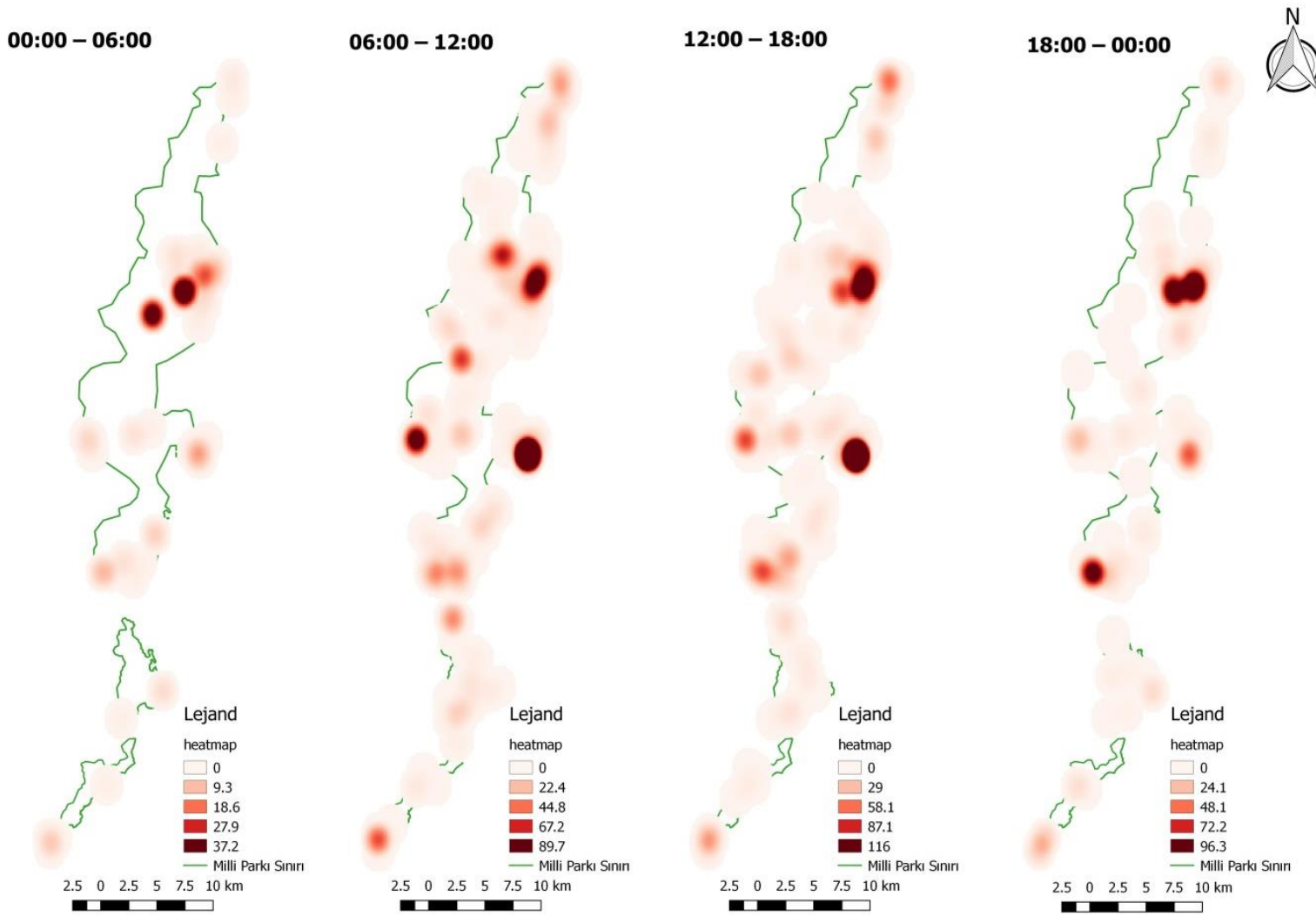

Şekil 12. Günün farklı saatleri için coğrafi etiketli fotoğraf yoğunluğu.

Analiz sonuçları hem mekân hem de saat dilimi açısından milli parkın dinamiğini ortaya çıkarmıştır. 00:00-06:00 aralığında Likya Yolu; 06:00-12:00 aralığında Phaselis Antik Kenti, Göynük Kanyonu, Likya Yolu ve Olympos Teleferik; 12:00-18:00 aralığında Phaselis Antik Kenti ve Göynük Kanyonu; 18:00-00:00 aralığında ise Yanartaş ve Göynük Kanyonu en fazla fotoğraf paylaşım yoğunluğuna sahip yerler olarak görülmüştür. Likya Yolu, uzun mesafeli bir yürüyüş yolu olduğu için ziyaretçilerin sabah erken saatlerde yürüyüşe başladıkları ve akşama kadar ziyaret deneyimlerini fotoğrafladıkları söylenebilir. Phaselis Antik Kenti tarihi doku ile doğal güzellikleri bir arada deneyimlemek isteyen ziyaretçiler tarafından öğleden önce ve öğleden sonraki saatlerde ilgi odağı haline geldiği tahmin edilmektedir. Olympos Teleferik hattı eşsiz panoramik manzaraları fotoğraflamak isteyen ziyaretçilerin cazibe merkezi haline geldiği tahmin edilmektedir. Göynük Kanyonunun öğleden önce ve öğleden sonraki saatlerde adrenalin yüklü aktiviteler gerçekleştirmek ve doğal güzellikleri keşfetmek isteyen ziyaretçilerin akınına uğradığı düşünülmektedir. Yanartaş'ın akşam ziyaretçi yoğunluğuna uğraması taşların arasından çıkan alevleri gece karanlığında fotoğraflamak istemeleri ile ilişkilendirilebilir.

Ziyaretçilerin mevsimsel davranışlarını incelemek amacıyla ilkbahar, yaz, sonbahar ve kış dönemleri için mekânsal analizler gerçekleştirilmiştir. Mevsimsel desenler, bir parkın işlevselliği ile birlikte iklimsel faktörlerin 
etkisini de yansıtabilir. Walden-Schreiner vd. (2018), Flickr'daki coğrafi etiketli fotoğrafların Aconcagua Eyalet Parki'nda (Arjantin) ve Kosciuszko Ulusal Parkı'nda (Avustralya) zamansal ve mekânsal kullanım modellerinin etkin nokta haritalarını ve dağıtım modellerini nasıl oluşturabileceğini araştırmışlardır. Araştırmada kıș aylarında kayak merkezlerinin ve kayak parkurlarının yoğun bir şekilde ziyaretçi akınına uğradığı, yaz aylarında ise ziyaretçilerin dağ bisikleti gibi aktiviteleri tercih ettikleri belirtilmiştir. Şekil 13 'te mevsimsel dönemlere ilişkin mekânsal analiz sonuçları gösterilmiştir

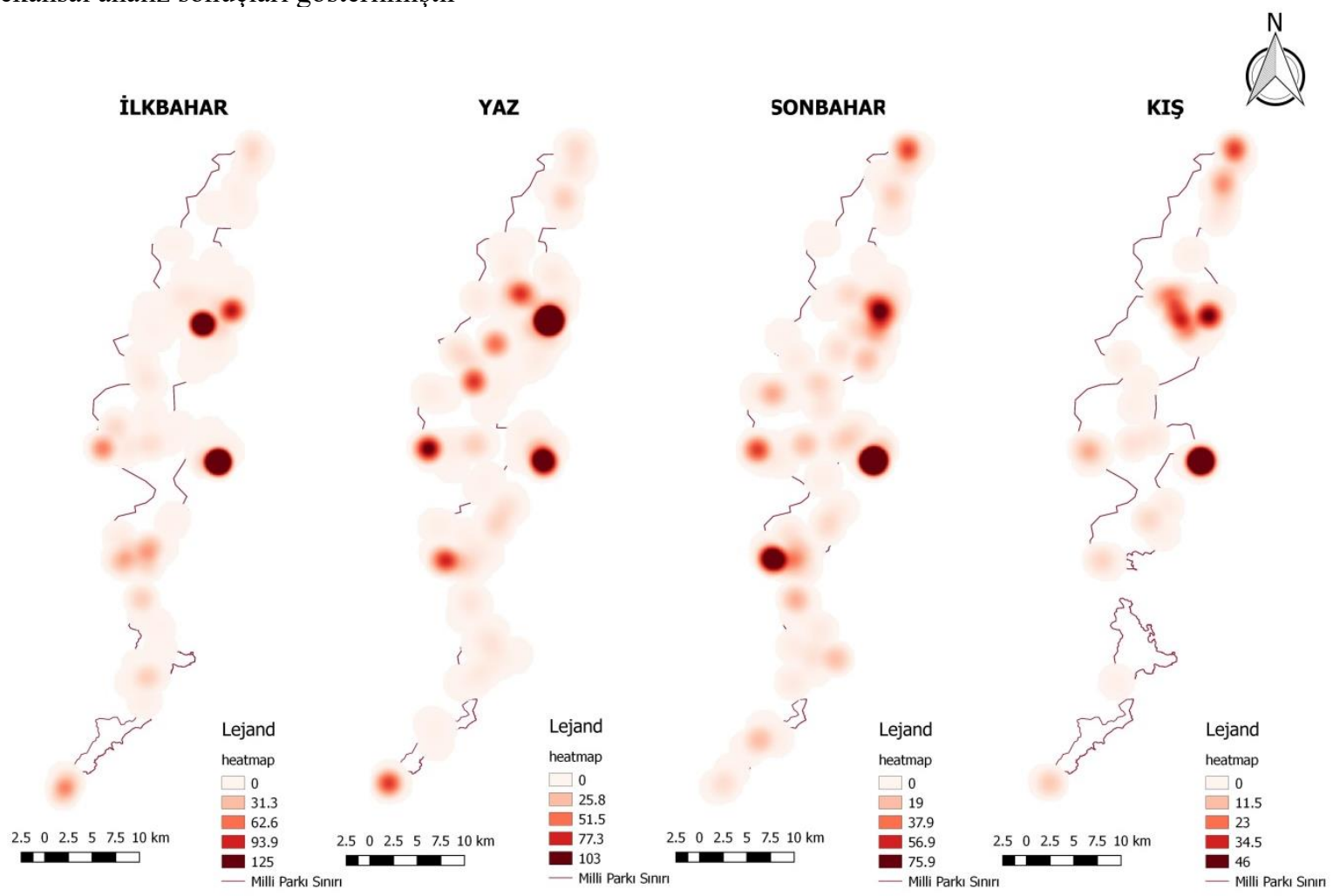

Şekil 13. Mevsimlere göre coğrafi etiketli fotoğraf yoğunluğu.

Analiz sonuçları hem mekân hem de mevsimsel açıdan milli parkın dinamiğini ortaya çıkarmıştır. İlkbahar mevsiminde Phaselis Antik Kenti, Göynük Kanyonu ve Likya Yolu; Yaz mevsiminde Phaselis Antik Kenti, Göynük Kanyonu, Likya Yolu ve Olympos Teleferik; Sonbahar mevsiminde Phaselis Antik Kenti, Göynük Kanyonu ve Yanartaş; Kış mevsiminde ise Phaselis Antik Kenti ve Likya Yolu en fazla fotoğraf paylaşım yoğunluğuna sahip yerler olarak görülmüştür. Mevsimlere bağlı olarak sıcaklık ve yağışın ziyaretçilerin mekânsal davranışı üzerinde, özellikle yürüyüş, dağcılık ve doğa sporları gibi özel rekreasyonel faaliyetlerin gerçekleştirilmesinde etkisi olduğu söylenebilir. Sıcak günlerde bazı ziyaretçiler daha yüksek rakımlara gidebilirken, diğer ziyaretçilerde daha düşük rakımlarda daha soğuk kanyonlarda veya denize yakın yerlerde bulunmayı tercih edebilirler. Bazı alanları ortalamadan daha soğuk günlerde ziyaret etme seçeneği olmayabilir.

Çalışmanın bulguları ziyaretçilerin Beydağları Sahil Milli Parkı'na yönelik davranışı üzerindeki mevsimsel etkileri, günün saatine, günün aralıklarına (sabah, öğleden sonra, akşam) ve haftanın gününe bağlı olarak ziyaretçi sayısındaki değişiklikleri ortaya koymuştur. Ayrıca bulgular konum tabanlı sosyal medya verilerinin milli park yönetimi için güncel ve daha ayrıntılı veriler elde etmek amacıyla tamamlayıcı veriler olarak kullanılabileceğini göstermektedir. Herhangi bir veri kaynağında olduğu gibi sosyal medyanın da sınırlamaları vardır. Facebook ve Instagram, 2019 yılı itibariyle gizlilik politikaları gereği veri paylaşımını durdurmuştur. Hiçbir yazılım, paket ya da ara yüzle bu platformlardan veri sağlanamamaktadır (Gülçin,2020). Dolayısıyla, bu çalışmanın sınırlılıklarından birisi yaygın olarak kullanılan diğer sosyal medya uygulamalarından coğrafi etiketli fotoğraf verilerinin elde edilememiş olmasıdır.

\section{Sonuç ve Öneriler}

Milli parklara ilişskin ziyaretçi verileri ve ziyaretçilerin zamansal-mekânsal davranış modelleri, park yönetimi ve doğa temelli turizm araştırmaları için çok önemlidir. Ziyaretçi bilgilerini elde etmenin genellikle zahmetli ve pahalı olduğu milli parklarda, konum tabanlı sosyal medya verileri bu bilgilere erişmek için alternatif bir veri kaynağı olarak kullanılmaktadır. Bu çalışmada, konum tabanlı sosyal medya platformu Flickr'dan alınan coğrafi 
etiketli fotoğrafların, ziyaretçi davranışının farklı yönlerini belirlemek için alternatif veri kaynağı olarak kullanılabilirliği araştırılmıştır. Beydağları Sahil Milli Parkı sınırları içinde ziyaretçiler tarafından Flickr platformunda paylaşılan coğrafi etiketli fotoğraflar kullanılarak yoğunluk haritaları ve zamansal eğilimler ile ziyaretçi davranışının derinlemesine analizi gerçekleştirilmiştir. Çalışmanın sonuçları, Phaselis Antik Kenti, Likya Yolu, Göynük Kanyonu, Olympos Teleferik Hattı ve Yanartaş mekânlarının, ziyaretçi faaliyetleri açısından merkezi yerler olduğunu ve en yoğun ziyaretlerin öğleden sonra gerçekleştirildiğini göstermiştir. Flickr verilerinin haftalık ve günlük dağılımları, en yoğun ziyaretçi dönemlerini belirlemeye, ziyaretçi yoğunluğunu yönetmek için ek önlemler almaya ve genel ziyaretçi deneyimini iyileştirmeye katkıda bulunabilecek değerli bilgiler sağlamıştır. Elde edilen sonuçlar, milli parklarda ziyaretçi izleme için yeni veri kaynaklarının potansiyelini ve gelecekteki araştırmalar için firsatlar sunduğunu göstermektedir.

\section{Kaynaklar}

1. Arkema, K. K., Fisher, D. M., Wyatt, K., Wood, S. A., Payne, H. J. (2021). Advancing Sustainable Development and Protected Area Management with Social Media-Based Tourism Data. Sustainability, 13(5), 2427.

2. Arslan, E. S., Örücü, Ö. K. (2020). Kültürel ekosistem hizmetlerinin sosyal medya fotoğrafları kullanılarak modellenmesi: Eskişehir örneği. Türkiye Ormancılık Dergisi, 21(1), 94-105.

3. Balmford, A., Beresford, J., Green, J., Naidoo, R., Walpole, M., Manica, A. (2009). A global perspective on trends in nature-based tourism. PLoS Biol, 7(6), e1000144.

4. Barros, C., Moya-Gómez, B., \& García-Palomares, J. C. (2019). Identifying temporal patterns of visitors to national parks through geotagged photographs. Sustainability, 11(24), 6983.

5. Barros, C., Moya-Gómez, B., Gutiérrez, J. (2020). Using geotagged photographs and GPS tracks from social networks to analyse visitor behaviour in national parks. Current Issues in Tourism, 23(10), 1291$1310 . \mathrm{g}$

6. Cessford, G., Muhar, A. (2003). Monitoring options for visitor numbers in national parks and natural areas. Journal for nature conservation, 11(4), 240-250.

7. Di Minin, E., Tenkanen, H., Toivonen, T. (2015). Prospects and challenges for social media data in conservation science. Frontiers in Environmental Science, 3, 63.

8. Gülçin, D. (2020). Kültürel ekosistem hizmetlerinin sosyal medya verileri kullanılarak haritalanması: Datça yarımadası örneği. Türkiye Ormancılık Dergisi, 21(4), 407-416.

9. Kovacs-Györi, A., Ristea, A., Kolcsar, R., Resch, B., Crivellari, A., Blaschke, T. (2018). Beyond spatial proximity - classifying parks and their visitors in London based on spatiotemporal and sentiment analysis of Twitter data. ISPRS International Journal of Geo-Information, 7(9), 378.

10. Heikinheimo, V., Minin, E. D., Tenkanen, H., Hausmann, A., Erkkonen, J., Toivonen, T. (2017). Usergenerated geographic information for visitor monitoring in a national park: A comparison of social media data and visitor survey. ISPRS International Journal of Geo-Information, 6(3), 85.

11. Levin, N., Lechner, A. M., Brown, G. (2017). An evaluation of crowdsourced information for assessing the visitation and perceived importance of protected areas. Applied geography, 79, 115-126.

12. Manning, R. E. (2002). How much is too much? Carrying capacity of national parks and protected areas. In Monitoring and management of visitor flows in recreational and protected areas. conference proceedings (pp. 306-313).

13. Schägner, J. P., Maes, J., Brander, L., Paracchini, M. L., Hartje, V., Dubois, G. (2017). Monitoring recreation across European nature areas: A geo-database of visitor counts, a review of literature and a call for a visitor counting reporting standard. Journal of outdoor recreation and tourism, 18, 44-55.

14. Shoval, N., Ahas, R. (2016). The use of tracking technologies in tourism research: the first decade. Tourism Geographies, 18(5), 587-606.

15. Sessions, C., Wood, S. A., Rabotyagov, S., Fisher, D. M. (2016). Measuring recreational visitation at US National Parks with crowd-sourced photographs. Journal of environmental management, 183, 703-711.

16. Ullah, H., Wan, W., Ali Haidery, S., Khan, N. U., Ebrahimpour, Z., Luo, T. (2019). Analyzing the spatiotemporal patterns in green spaces for urban studies using location-based social media data. ISPRS International Journal of Geo-Information, 8(11), 506.

17. Walden-Schreiner, C., Rossi, S. D., Barros, A., Pickering, C., Leung, Y. F. (2018). Using crowd-sourced photos to assess seasonal patterns of visitor use in mountain-protected areas. Ambio, 47(7), 781-793.

18. Xie, Z., Yan, J. (2008). Kernel density estimation of traffic accidents in a network space. Computers, environment and urban systems, 32(5), 396-406.

19. URL-1: http://beydaglari.tabiat.gov.tr/, (15.03.2021).

20. URL-2: https://www.flickr.com/, (18.03.2021).

21. URL-3: https://www.python.org, (18.03.2021). 